\title{
Thinking and theorising about activism: who and how?
}

\author{
Elizabeth Humphrys
}

\begin{abstract}
This article overviews the following three papers, which arise from the 2008 conference Other Worlds 2: After the Neo-Con Men. The article responds to an issue raised across the papers regarding social movement knowledge and theory: what is the tension between analysis produced inside the academy and that which arises from within movements. And how can theory can be developed in a way that both takes into account the viewpoint and needs of the historical players whose activity is shaping the future (social movement actors) and the wider social forces that give rise to and shape the struggles those players are involved in.

It is argued that the new movements around globalisation and global justice have reasserted 'activism' as a key component of social movement analysis, challenging academics to engage with social movements in a more direct way and to ensure their output is relevant to that audience. It is argued that the concept of the 'organic intellectuals', outlined by Italian Marxist philosopher Antonio Gramsci, has particular utility.
\end{abstract}

Late in the evening on September 112001 I was back in my childhood bed. My life was a whirlwind of activity as I had just quit my job, was about to vacate my house and was preparing to move from Melbourne to Sydney for the second time in my life. The latter is never an easy task for a Victorian. I was slightly nervous and distracted in the middle of these changes, but I was at relative peace with the world personally and politically. The global justice movement was gathering momentum in Australia in the wake of the Seattle alter-globalisation protests and the protests on s11 at the Crown Casino in Melbourne ${ }^{1}$, and I was working hard organising a gay and lesbian contingent to the protest against the upcoming Commonwealth Heads of Government Meeting in Brisbane in October.

Although my brother and I had left the family home some time ago, we were both staying at the house while our mother was away. Up late watching soccer, my brother was the first of us to see the collapsing twin towers on news broadcast. In a dazed state he came to wake me and for some

\footnotetext{
${ }^{1}$ On September 11, 12 and 132001 an estimated 20 thousand people protested at the World Economic Forum held at Crown Casino in Melbourne. Commonly known as the s11 protests, activists formed a human barrier to the conference venue and were successful on the first day of the forum in stopping a number of delegates from attending.
} 
time we sat together, stunned, watching incredible images beamed from New York City to a suburban Melbourne house. Very little was said. Then the phone calls began.

That night I must have spoken to a dozen activists about the attacks, including what they might mean for both US-Middle East relations and the global justice movement. The phone calls were our first attempt to re-theorise our social movement activity in light of what would be considerably altered circumstances. What would happen to the movement? What was now the key issue to campaign over given the likely military retaliation from the US? How had our personal views of the world and how to change it been challenged or altered?

While the circumstances of these calls were unusual, the process underway was not. Theorising and conceptualising movement activism is bread and butter for many social movement activists, who constantly need to assess and reassess their activity in light of the wider economic and political context. This theorising is either within movements themselves or within left political organisations, or in a more public way carried on through blogs (such as capitald17 based in the UK or againstthegrain or adbusters based in the US), magazines (Left Turn: Notes from the Global Intafada and CounterPunch) and political commentary facilities within electronic infrastructure such as Indymedia. Academic analysis is of course mostly published within academic journals.

Despite the constant debate and dialogue within and between movements, many portray them as amorphous masses where there is little dialogue and questioning. In analysing global justice movement events in Australia for example, the mainstream media has often sought to explain the mass struggle as being the work of a few individuals who manipulate the wider group for their own (often hidden) agenda. While most activists see their efforts as involving both activity to achieve aims, and taking part in a discursive and dialogical process that articulates and theorises what needs to be done in the current circumstances, this nuance finds difficulty in making its way onto the front page of the Sydney Morning Herald or The Age. Activists of course 'do' things, but they also strategise how to do them and envisage a different future. 
When first thinking about the conference Other Words 2: Beyond the Neo-Con Men, I wanted the event to be a place where activists and academics could come together to discuss a number of common concerns and issues. While activists and academics are not divided physically, and many individuals encompass both those roles, the world of theoretical development can be separated into research done within the academy and outside it. In Australia there are a few publications that seek to straddle these worlds - the journal Overland being one such example and a number of academics have sought to publish works regarding social movements that are accessible and jump the language barrier. Verity Burgmann's book Power, Profit and Protest (2003) is perhaps the best example of this.

For this reason, the panel Beyond Activism and the keynote address to the conference heard from people who inhabit both the worlds of activism and academia. They have divergent views and prosecute differing strategies regarding social movement activity. All have been involved in campaigns, many as leading members and spokespeople. A number of the speakers have been central to a particular social movement, including the campaign to end mandatory detention of refugees and the Your Rights At Work campaign. A number are also members of political parties - from the revolutionary to the reformist, and from the small to the mass based. One of the key questions asked by each of these speakers is What is Politics?

\section{Beyond Activism}

The status quo assumes passivity and deference, it downplays human agency and counsels against action. Yet it is impossible to imagine social movements without activists and activism people and their actions that create, energise and shape struggles for justice, rights and a better world.

The emergence of movements for another globalisation - another world - over the last decade have once again brought questions of activism to the fore of debate (Cockburn and St. Clair 2000; Bello 2001; Callinicos 2003; Bevington and Dixon 2005). In Australia this movement was at its strongest at the s11 protests at Crown Casino (Iveson and Scamler 2000), but could also be seen in the vibrancy of the No Borders movement against the mandatory detention of asylum seekers (Maksimovic and Barnes 2002; Stead 2002) and alternative media initiatives such as 
Indymedia (Meikle 2003). Alongside the movements for another globalisation have been significant mobilisations and campaigns over the Iraq War and Australian Guantanamo Bay detainee David Hicks.

The strength of these new struggles has often been their spontaneity and autonomy, taking the corridors of power by surprise and disrupting them. For example, when the big business and institutional delegates to the Word Economic Forum meeting in Melbourne arrived at the Crown Casino on that September morning 2000, they found their very ability to access the building blocked by thousands of protesters. Many delegates did not make it past the blockade. Despite the success of the North American activists in blocking access to the World Trade Organisation meeting in Seattle in 1999, politicians and business leaders alike seemed perplexed that similar events could occur in the Central Business District of Melbourne. New agendas of resistance and alternatives have been thrust upon the mainstream debate, and for while, it appeared every young student activist had a copy of Empire (Hardt and Negri 2001) weighing down their book bag.

Everywhere activists have been drawn to extolling the virtues of network politics and decentralised organisation (Klein 2001; Hardt and Negri 2004), and centralising projects and programmatic debate have been dismissed as authoritarian and antidemocratic, with many activists rejecting parties outright. Naomi Klein has spoken of the new movements being like a 'swarm' (Klein 2000) rather then resembling the political organisations of the past, and in its founding charter the World Social Forum even excluded political parties from participating (World Social Forum International Council 2001). In this volume, Damien Lawson offers a consideration of this political trajectory. After the s11 protest many also argued to focus attention on local campaigns, in order to build a more coherent and organised left, even if this was at the expense of being involved in the wider movement critical of globalisation or protests directed at international institutions such as the World Bank and International Monetary Fund.

Others argued that progress would be made through the accumulation of victories on key specific issues. In this vein many activists threw themselves at the challenge posed by the Howard Government's WorkChoices legislation, and gave birth to a highly organised campaign around working people's rights. Centralised planning, national advertising, highly crafted media strategy 
and funded local organisers in marginal seats were some of the hallmarks. Ultimately, these campaigns delivered to Kevin Rudd and the Australian Labor Party (ALP) a most convincing federal election win in November 2007 even if the 'ALP did not publicly credit the...campaign as playing a significant - or even any - role in their victory' (Muir 2008).

But are such polarised positions - the centralised or decentralised social movement strategy sufficient in the present conjuncture? And what is the role of activists themselves in generating political theory both specific to Australia and global in its appreciation and context?

Clearly the events on September 112001 opened the possibility for an unholy alliance of free market globalisers and US neo-conservative militarists to promulgate their own version of globalisation through the barrel of a gun. Wars were launched against Afghanistan and Iraq in order to promote the interests of the world's largest capitalist economy, the United States. At the same time they once again stepped on to the front foot with their drive to open up markets in the pursuit of those same interests.

While the advancement of the neo-cons in this context initially wrong-footed the burgeoning global justice movement, resistance to their agenda soon erupted in another form across the world. The movement against the Iraq War saw the largest street protests in world history in early $2003^{2}$, as well as ongoing campaigning as the United States' imperial project began to come apart at the seams. In the process of reconstructing the global justice movement in and around the movement against the Iraq War, the activists involved in the protests at Crown Casino had to rethink goals and methods, and more broadly activists and intellectuals were forced to confront difficult theoretical and practical questions.

Despite the decline of the Bush, Blair and Howard regimes, the need for campaigners to further clarify their positions and trajectories has not diminished. Even in an era 'after the neo-cons' (and more recently 'after the neo-liberals') the need for progressive thinkers to sharpen their intellectual armoury is as relevant as ever.

\footnotetext{
${ }^{2}$ The combined numbers of protesters on street demonstrations between 3 January and 12 April 2003 is estimated at 36 million by French academic Dominic Reynie, according to Callinicos (2003b).
} 
The Beyond Activism panel at the After the Neo-Con Men conference in April 2008 looked at the question of the role of campaigns, movements and manifestos in achieving social change. The character of each of these was considered - sometimes in isolation, sometimes in their relevance to each other on a continuum - through questions such as 'how do campaigns on single issues relate to wider movements for change?' and 'what role is there for manifestos of political programs within activist activity?’. A key concern of those presenting was how activists, campaigns and movements might effectively move beyond oppositionalism, beyond activism, to both theorise and implement agendas for change.

The panel also examined the re-emergence of strategic and political questions within and around movements and struggles. In developing their papers the panel were asked to consider the following three areas of activist work and theory development:

The limits of activism: How do activists relate to movements and campaigns? How do they seek to engage with wider debates and communities? How do they mobilise to achieve change and what stands in the way of their goals? How do they relate to parties and politicians?

Spatial dialectics of struggle: Movements are often born locally but how do they strive for national or global reach? What visions connect the particular struggle to a wider movement? How do activists reconcile the tension between a global agenda for change and the national boundaries of official politics? What happens when movements and states come into conflict?

The return of politics: When do activists feel the limits of movement politics? What is the logic of political representation: an active or passive process? Do manifestos help or hinder struggles? What happens when parties compete for hegemony within movements? How can strategy be formulated, debated and implemented? Can movements outsmart their opponents in power and, if so, how? If we're going to change the world, do we really need to take power?

\section{Movement relevant theory}

This panel of the conference was envisaged as a place where activists and academics could meet to discuss social movements in contemporary Australia. While it is not always a clear distinction 
- who is an activist and who is an academic - in recent years a growing number of theorists have questioned the role played by social movement research within the academy (Goodwin and Jasper 1999; Bevington and Dixon 2005; Maddison and Scalmer 2006), and in part sought to plot a new course to reengage these two spheres of analysis.

Amongst these academics, there have been two arguments in particular prosecuted about the role of social movement research. Firstly, it has been argued that social movement research has a history of being abstracted from the real questions that face social movements and that the research conducted makes only a limited contribution to the networks and movements it analyses (ibid 1999 and 2005). Secondly, it has been argued that it is possible to re-imagine social movement research as movement-relevant and movement-engaged through a different methodological approach (ibid 2005).

Douglas Bevington and Chris Dixon outline in their article 'Movement-relevant Theory: Rethinking Social Movement Scholarship and Activism’ (2005) a new methodological framework that might begin to deal with how we arrived at a disjuncture between social movement research and movement concerns. In effect, they argue for theory that is more 'ground up’. They propose a new research process, which involves ‘direct engagement with movements in the formulation, production, refinement, and application of the research' (ibid). Rather than seeking some form of constructed 'distance' from movements, it is the 'researcher's connection to the movement [which] provides important incentives to produce more accurate information, regardless of whether the researcher is studying a favoured movement or its opponents'. It is through such direct engagement that theories can be refined and reflected on. Additionally, the research is not simply informed by the movement but accountable to it. While in some aspects this approach may be similar to participatory action research, it differs in that the results and findings are not arrived at 'together'. While direct engagement with movements is necessary, activists are not co-researchers and do not control the direction of and final product of the research in that way.

These authors outline a number of factors in creating movement-relevant research: locating the issues and questions of importance to movement participants; creating a dialogue with movement 
participants; and having research read by movement activists and incorporated into movement strategising. It is through direct contact with movements, and an examination of the debates and dialogue occurring within a particular movement, that key issues and questions can be identified. As has been discussed by social movement researchers like the authors of Activist Wisdom (Maddison and Scalmer 2006), it is not only within the academy that social movement theory and analysis takes place. Movements themselves perform this task, albeit often in their own language and in terms that might appear idiosyncratic to an 'outsider'.

Activist Wisdom was a particularly appealing read for social movement activists, as they saw themselves as the active (and respected) subject in a widely distributed publication from a significant academic publishing house. While clearly a sympathetic audience, Maddison and Scalmer seek to place activists, their skills and political analysis at the centre of social movement thinking in Australia.

The approach of authors like those of Activist Wisdom is a breath of fresh air compared with many of their colleagues in the academic world who conduct research without a dialogue with movement participants. With a similar outlook to that suggested by Bevington and Dixon, Maddison and Scalmer explore key questions activists confront at this time. This is not to say, however, that the acceptance without critique of the views of activists is the aim or indeed appropriate. A key concern is that by accepting the standpoint of activists without a critical analysis, the framework in which movement participants find themselves may come to colour and skew researchers' ability to achieve theoretical insights that have relevance beyond the movement's bounds.

Indeed, because social movements are by definition partial features of the historical process rather than encompassing the totality of human experience, important insights about the social substrate on which movements develop may be lost if seen only from the prism of participants.

How then can someone theorise in a way that both takes into account the viewpoint and needs of the historical players whose activity is shaping the future, and the wider social forces that give rise to and shape the struggles those players are involved in? On the one hand academics are 
being criticised for being distant and disengaged, their work lacking relevance or use to those researched. On the other activists can be, and in my experience often are, prone to seeing only a partial view of a wider political dynamic.

It is here that a concept famously outlined by Italian Marxist philosopher Antonio Gramsci in his Prison Notebooks (1971) has particular utility. Gramsci argues that for the working class movement to challenge the hegemony of the ruling class there needs to be the creation of a stratum of 'organic intellectuals' from within its ranks. These are workers who have a clear conception of the world and the aims of their movement, not just one or the other. He distinguishes this group from the common understanding of intellectuals as abstract thinkers or academics, and instead compares it with the organic intellectuals of the bourgeoisie like judges, lawyers, engineers and economists (Gramsci 1971; Molyneux 1978).

While Gramsci believes that the recruitment of a layer of non-proletarian intellectuals to the working class movement is an important factor in the struggle for hegemony, this is not the key. Rather, it is to develop 'intellectuals of a new type which arise directly out of the masses, but remain in contact with them to become, as it were, the whalebone in the corset' (Gramsci 1971; quoted in Molyneux 1978). He goes on to argue that political parties are the natural expression of this process, the way by which such a stratum coheres itself within the wider movement or class: 'The political party for some social groups is nothing other than their specific way or elaborating their own category of organic intellectuals directly in the political and philosophical field...' (Gramsci 1971).

In Gramsci's view, then, the solution to the problem of how to theorise movement practice without either separation from the movement or reduction to its lowest common denominator is solved through the intertwining of two processes. First, the creation of a layer of activists developing theory but also remaining firmly rooted within the movement. Second, their agglomeration in an organisation in which they can discuss and debate ideas in the process of leading movement struggles. Contrary to the views of many activists who explicitly reject ideas of party organisation as inherently authoritarian (Hardt and Negri 2001; Sentas 2002; Hardt and 
Negri 2004), Gramsci sees such organisation as vital to strengthening the intellectual forces of oppositional movements and classes fighting for liberty.

In the current situation, this concept of the organic intellectual is useful as it allows us to appreciate how the development of ideas can occur not only from within movements and from their point of view but also articulating a broader vision not reducible to the movements or their participants. These individuals are 'of' the social movement, but also have horizons beyond it. They are able to both fight for the broadest and largest movement possible, but also able to fight for their own political vision within it.

\section{The presentations and papers}

While academics like Bevington and Dixon suggest a 'direct engagement' process for academic work, they do not propose a political or historical framework in which their findings will be analysed. It is here that each social movement researcher or activist must wade in - and this is indeed what each of the conference participants appearing in this section of the journal did. Not only did they bring insights about their own activism, but also their views of the world around them and where the movements they are enmeshed in sit within that wider frame.

Each of the presenters asked the audience to consider that changes were needed to how social movements do their business - how campaigns are run, how movements and networks form and coalesce, and what the role of organised parties and political organisations should be. In assessing these questions our writers here seek to critique the theoretical perspectives and activity they believe are dominant in Australian social movements at present. In this way, each of the papers differs by focusing on a particular aspect of this question.

Each paper was also a call to activists to do better, and to be better. The papers urge activists to involve themselves in social movement planning over the medium and longer term in a more significant way.

The keynote address opening the conference was from Australian Services Union Secretary Sally McManus. McManus presented to the audience her analysis of the Your Rights At Work 
campaign, arguing that a totalising view of the campaign is necessary in order to understand how the movement built. She urges activists not to seek the key tactic that won the day, almost as if there is a silver bullet, but to understand that each movement has many tactics and strategies that take it forward in particular circumstances. McManus noted the ability of the Your Rights At Work national campaign leadership to debate issues intensely, but then agree on a strategy and implement it in a united way. She also wanted to make clear that the movement could not have been successful without the bottom up organising of the local Your Rights at Work groups, and in the spirit of Gramsci pointing out that the local organisers were the organic intellectuals that took each group in each town forward in those particular local circumstances.

In opening the panel, Amanda Tattersall looked at a number of local and global movements from the Your Rights At Work campaign and Get Up! more locally, to a campaign against WalMart in North America. Tattersall feels there are three key messages for movement organisers in Australia at present. She believes that movement organisations are debilitated and weak, and that they need to be rebuilt. Importantly, she argues that there is a particular framework in which this rebuilding needs to occur, in that these organisations must be reconstructed from the bottom up. Politically, Tattersall argues that an unambiguous moral vision is urgently needed where activists set and fight for clear goals. At the present conjuncture, Tattersall believes progressive movements fall too easily into abstraction and propaganda rather than seeing that political argument and movement building are things that work hand in hand. Involved in organising the Sydney Alliance ${ }^{3}$, a coalition of community groups, faith organisations and unions that has come together to shape the quality of urban life in Sydney, these are the questions that Tattersall hopes to address in practice over the next four years.

Jess Whyte stood back from the practicalities of any one campaign or movement, and looked at the question of political organising in a different way. The paper she has provided for this issue traverses the rise of the neo-cons and the fall of the Berlin Wall in addressing the question of how we arrived 'here'. She implores activists to 'rethink the fundamental assumptions of liberalism, and of a political practice centred on progress, sovereignty and right[s]'. In picking up a theme from a previous panel, Whyte contemplates whether a focus on 'rights' has indeed

\footnotetext{
${ }^{3}$ See ncoss.org.au/projects/enews/downloads/Sydney_Alliance_Article_Ncoss.pdf for more information.
} 
limited what we, as activists, believe is possible. She wonders whether in the wake of the 9/11 attacks in New York and Washington we are now trapped, as conservatives call for the 'right to security' and 'right to democracy'. Like Tattersall, Whyte demands we do more and be more but she also articulately demands that we re-imagine what it is we desire and believe is possible; that we, in fact, demand the impossible under capitalism.

The final part of our panel was a paper jointly written and delivered by Rick Kuhn and Diane Fields, which does not appear in this volume. Both Kuhn and Fields are activists and academics, and their talk and paper argued for a revival of the Marxist approach to social movement analysis. They argued the importance of a political party in taking social movement objectives forward. They suggested that the new imaginings of those arguing for network based politics over party based organising, something that was also discussed in the first panel regarding movement 'vehicles' for change, are in fact old ideas remade. It is these ideas, they believe, that have repeatedly held back progressive movements in the past. Kuhn and Fields assert that we must not only assess what is happening now, but that we must appreciate the history of social movement struggle in order to inform activity today.

In considering the papers presented in this journal and reflecting on what each of the presenters argued, it is clear that a number of positions and discussions emerge as to how movements develop. For Tattersall it is the process of outreach and community strengthening that will allow common political agendas to be forged. For Whyte, it is the primacy of articulating a radically transformative politics that constantly points in a direction beyond the limits self imposed by movements for reform. And for McManus the key is perhaps the solidarity and unity that can be forged in struggle, in order both tackle individual political questions but also to rebuild solidarity within a broader movement.

Of course a panel is only one part of a conference session, and written papers only one phase of a journal. After the final panel members had spoken, a lively discussion ensued with old wounds and new dreams both present. It is your turn now. After reading these papers we hope the dialogue we commenced on that day continues with you and amongst your friends and colleagues. The real change that we must achieve will come not simply from the bright ideas 
spoken from the front of a conference room, but from the dialogue and practice that comes out of that.

The next step is in your hands as we enter a period analogous to that Gramsci was discussing when he stated that:

a crisis occurs, sometimes lasting for decades. This exceptional duration means that incurable structural contradictions have revealed themselves ... and that, despite this, the political forces which are struggling to conserve and defend the existing structure itself are making every effort to cure them (1971, p 178).

As certain forces look to cure old ills, others, and in particular social movements, look to remake the world anew along a new path.

\section{References}

Bello, W. 2001, '2000: The Year of Global Protest', International Socialism Journal, vol.2, no. 90, pp. 171-76.

Bevington, D. and C. Dixon 2005, 'Movement-Relevant Theory: Rethinking Social Movement Scholarship and Activism', Social Movement Studies, vol.4, no. 2, pp. 185-208.

Burgmann, V. 2003, Power, Profit and Protest: Australian Social Movements and Globalisation, Crows Nest, Allen \& Unwin.

Callinicos, A. 2003a, An Anti-Capitalist Manifesto, Cambridge, Polity.

Callinicos, A. 2003b, 'War Under Attack', Socialist Review, April 2003.

Callinicos, A. 2005, 'Anti-war protests do make the difference', Socialist Worker, London, 1943.

Cockburn, A. and J. St. Clair 2000, 5 Days that Shook the World, London, Verso.

Goodwin, J. and J. Jasper 1999, 'Caught in a Winding, Snarling Vine: The Structural Bias of Political Process Theory', Sociological Forum, vol.14, no. 1, pp. 27-54.

Gramsci, A. 1971, Selections from the Prisons Notebooks, London, Lawrence and Wishart.

Hardt, M. and A. Negri 2001, Empire, Cambridge, Harvard University Press.

Hardt, M. and A. Negri 2004, Multitude, New York, The Penguin Press.

Iveson, K. and S. Scamler 2000, 'Contesting the 'Inevitable': Notes on S11', Overland, no. 161 pp. 4-13.

Klein, N. 2000, 'The Vision Thing', The Nation.

Klein, N. 2001, 'Reclaiming the Commons', New Left Review, vol.2, no. 9, pp. 81-89.

Maddison, S. and S. Scalmer 2006, Activist Wisdom, Sydney, University of New South Wales Press.

Maksimovic, A. and T. Barnes 2002, 'Woomera2002', CounterAction, vol.1, pp. 28-29.

Meikle, G. 2003, 'Indymedia and the New Net News', M/C Journal,vol.6, no. 2. 
Molyneux, J. 1978, Marxism and the Party, London, Pluto Press.

Muir, K. 2008, Worth Fighting For: Inside the Your Rights at Work Campaign, Sydney, UNSW Press.

Sentas, V. 2002, 'The Social Centre Experiment: (or, Sketches of a Decentralised Matrix of Liberation!)', CounterAction, vol.1, pp. 20-22.

Stead, V. 2002, 'No One Is Illegal', CounterAction, vol.1, pp.32.

World Social Forum International Council 2001, 'World Social Forum Charter of Principles, Retrieved 4 March 2008, from

http://www.forumsocialmundial.org.br/main.php?id_menu=4\&cd_language=2. 